Open Access

\title{
Assessing the impact of eco-innovations through sustainability indicators: the case of the commercial tea plantation industry in Sri Lanka
}

\author{
A. D. Nuwan Gunarathne $e^{1,2^{*}}$ and H. M. P. Peiris 3,4
}

\footnotetext{
* Correspondence: nuwan@sjp.ac.lk; nuwan.gunarathne@griffithuni.edu.au 'Department of Accounting, University of Sri Jayewardenepura, Nugegoda, Sri Lanka ${ }^{2}$ Griffith Business School, Griffith University, Gold Coast, Australia Full list of author information is available at the end of the article
}

\begin{abstract}
Innovative processes aimed at sustainable development or eco-innovations have received increasing attention during the past years despite the lack of theoretical and methodological approaches to analyzing their impact. This paper focuses on how sustainability indicators can be used to measure the effects of "non-technical" ecoinnovations in the Sri Lankan tea plantation sector. After carrying out an experimental case study on a commercial tea plantation, we employed a combination of physical and monetary sustainability indicators to evaluate the initial results of the ecoinnovation. It shows that innovations aimed at improving economic benefits often result in unintentional environmental and social benefits that support a lean-green relationship. It reveals the difficulty in having a standardized set of indicators to measure the impact of eco-innovations owing to the multidimensionality of sustainability. Hence, the case study suggests adopting broad sustainability indicators that represent the wholeness of the system while capturing the long-term impact.
\end{abstract}

Keywords: Agriculture, Eco-innovation, Sri Lanka, Sustainability, Sustainability accounting, Sustainability indicators, Tea industry, Triple bottom line

\section{Introduction}

The recent expansion of economic activity has been accompanied by growing global environmental and social concerns (Organisation for Economic Co-operation and Development (OECD) 2009). While posing many challenges, they also provide opportunities for businesses to engage in sustainability practices and transform their businesses so as to contribute to sustainable development (Schaltegger et al. 2017). In this context, innovation is increasingly becoming an important supportive vehicle for developing corporate sustainability management as a means both of survival and growth (Han et al. 1998; Schaltegger et al. 2017). Hence, innovation processes aimed at sustainable development (eco-innovations) have received increasing attention in recent years (Bossle et al. 2016; Marin and Lotti 2017; Provasnek et al. 2017). When pursuing sustainability initiatives including eco-innovations, the first issue to address is its assessment (Keeble et al. 2003). Since sustainability is a multidimensional concept, its measurement should consider and integrate economic, social and environmental

(c) The Author(s). 2017 Open Access This article is distributed under the terms of the Creative Commons Attribution 4.0 International License (http://creativecommons.org/licenses/by/4.0/), which permits unrestricted use, distribution, and reproduction in any medium, provided you give appropriate credit to the original author(s) and the source, provide a link to the Creative Commons license, and indicate if changes were made. 
aspects (Pope et al. 2004). Sustainability performance is a construct, and hence cannot be observed; it should therefore be anchored in observable reality by means of indicators (Escrig-Olmedo et al. 2017). Further, the measure of sustainability depends to a great extent on the indicators used (Boggia and Cortina 2010). Similarly, information plays a key role in the process of creating and diffusing sustainability innovations (Schaltegger et al. 2017). There should be mechanisms to assess the effectiveness of eco-innovations from economic, social and environmental perspectives. That is, there should be proper monitoring, measurement and evaluations regarding the progress towards the sustainability goals (Sroufe et al. 2002). However, the assessment of the impact of eco-innovations is still not adequately developed in industries such as plantation agriculture $^{1}$ unlike in the manufacturing sector (Ariza et al. 2013). Innovations in the agriculture sector are of importance because the shrinking availability and the rising cost of land, labour, water and energy pose many challenges for the industry (UN Environment Programme (UNEP) 2008). With the constant growth of population there is pressure to increase agricultural yields, which often means the use of synthetic inputs that are not environmentally friendly such as pesticides or questionable such as genetically modified crops. In order to meet these rising environmental and sustainability challenges, the agriculture industry has yet to use innovation as a tool (Negny et al. 2012; Berdegue and Escobar 2002; Diederen et al. 2003). This case study presents an approach to improving the yield while being green and how to measure those improvements in the agriculture industry. As such, the paper presents how sustainability indicators can be used to measure the effects of eco-innovations from economic, environmental and social perspectives in the Sri Lankan tea plantation sector. The literature usually recommends that a company first begins with simple, easy-to-implement measures of resource efficiency before moving into more complex indicators (Krajnc and Glavič 2003). We therefore base this paper on the initial outcomes of an experimental case study conducted on a commercial tea garden using some selected sustainability measures.

The contributions of the paper are as follows: First, the paper adds to the growing body of sustainability assessment literature (see Hamilton and Atkinson 2006; Boggia and Cortina 2010; Escrig-Olmedo et al. 2017; Krajnc and Glavič 2003) by specifically focusing on eco-innovations. In doing so, this paper develops economic and environmental indicators and to a certain extent some social indicators to assess the impact of eco-innovations. The integration of ecological, social and economic aspects is very useful for extending innovation research to sustainable development (Rennings 2000). Second, the interdisciplinary nature of this study highlights the benefits for the plantation agriculture industry and for accounting (more broadly, business management) disciplines. This ecoinnovation is based on the principles and behaviour of plant physiology and was primarily aimed at productivity improvements to derive economic gains, but eventually resulted in environmental benefits as a byproduct (Horbach et al. 2012; Organisation for Economic Co-operation and Development (OECD) 2009; Carrillo-Hermosilla et al. 2010). Hence, this study provides evidence on the lean-green relationship from the agriculture industry. From the perspective of the plantation agriculture industry, this study shows how "nontechnical"2eco-innovations can be used to reduce their environmental impact while achieving economic benefits. This is particularly important since innovation is lacking in this industry (Ariza et al. 2013; Berdegue and Escobar 2002; Diederen et al. 2003). These types of innovations do not require advanced technology or large amounts of capital 
investment. Hence it has the potential to foster productivity levels on the agricultural plantations sector irrespective of the degree of development and growing conditions. However, the magnitude of benefits will vary with local environmental conditions. Since most of the tea producing countries are developing countries with low levels of technological development and capital investment constraints, these types of eco-innovations have the potential to improve productivity easily (Feder et al. 1985; Ongong and Ochieng 2013; Pretty et al. 2003). Since the plantation industry plays a significant economic role in these economies in terms of foreign exchange earnings and employment generation, the application and subsequent assessment of eco-innovation is of paramount importance in the face of intense pressure for better productivity and efficient resource utilization in achieving sustainable development. For the accounting discipline, this study expands the application of environmental and sustainability management accounting (EMA) $)^{3}$ beyond industries such as manufacturing or service where it is commonly used. Hence it shows the usability of EMA across a wide spectrum of industries provided the appropriate indicators and mechanism are used to provide information for stakeholders.

The rest of the paper is organized as follows: The next section presents the concept of eco-innovation and its assessment through sustainability indicators. Section three provides an overview of the tea industry followed by section four on the method adopted in the case study. Sections five and six present the analysis and discussion of the study respectively. The last section provides the conclusions and directions for further research.

\section{Eco-innovations}

Innovations play a major role not only in formulating national and international economic policies but also in devising strategies for achieving sustainable development (Rennings 2000). While the concept of invention refers to a discovery, the majority of innovations are not based on discovery but are the outcome of applied research and development (Kemp and Pearson 2008). Organisation for Economic Co-operation and Development (OECD) (2005) suggests four types of innovations: product innovations, process innovations, organisational innovations and marketing innovations. This paper focuses on process innovation within the broad definition of innovation. According to Organisation for Economic Co-operation and Development (OECD) (2005), process innovation is "the implementation of a new or significantly improved production or delivery method" (Organisation for Economic Co-operation and Development (OECD) 2005, p. 49). Process innovations include significant changes in techniques, equipment and/or software by reducing unit costs (Kammerer 2009; Organisation for Economic Co-operation and Development (OECD) 2005; Rennings 2000) and/or improving quality (Organisation for Economic Co-operation and Development (OECD) 2005). Hence the focus is on improving the existing processes or adding new processes (Carrillo-Hermosilla et al. 2010). Despite the usefulness of this general categorization (Carrillo-Hermosilla et al. 2010), OECD categories are not sufficient for dealing with the issues of sustainable development since they do not distinguish between environmental and non-environmental innovations (Rennings 2000).

To be an eco-innovation, an innovation should be less environmentally harmful than the relevant alternatives (Kemp and Pearson 2008). Hence in a widely cited definition, Kemp and Pearson (2008) define eco-innovation as: 
"The production, assimilation or exploitation of a product, production process, service or management or business method that is novel to the organisation (developing or adopting it) and which results, throughout its life cycle, in a reduction of environmental risk, pollution and other negative impacts of resource use (including energy use) compared to relevant alternatives". (p. 7)

The focus of the above definition is on the results of innovations as opposed to motivation (Horbach et al. 2012). Hence it is not necessary for eco-innovations to be motivated primarily by environmental improvements (Carrillo-Hermosilla et al. 2010). It could also result as a by-product of an economic motivation to reduce costs or improve market share (Horbach et al. 2012; Organisation for Economic Co-operation and Development (OECD) 2009). Hence, eco-innovations can be "environmentally motivated innovations" or "environmentally beneficial normal innovations" (Carrillo-Hermosilla et al. 2010). Effective tools are needed to ensure the success of various environmental management practices (Sroufe et al. 2002) including eco-innovations. Yet, there is still a lack of theoretical and methodological approaches to analysing the impact of eco-innovation.

When measuring the impact of sustainable initiatives such as such sustainability production, it is difficult to have a standardized set of sustainability indicators. This is due to the enormous differences between production facilities (Veleva and Ellenbecker 2001; Krajnc and Glavič 2003; Arundel and Kemp 2009). As a solution, Veleva and Ellenbecker (2001) suggest using a combination of core and supplemental indicators in the economic, environmental and social spheres. Core indicators are calculated based on the available data using commonly measured aspects such as water use, energy use and employee. They represent a standard set of indicators that can be applied in any situation. On the other hand, supplemental indicators openly set and vary between companies/facilities. They are used to introduce flexibility by addressing additional, production-specific aspects (Veleva and Ellenbecker 2001). The environmental indicators can be input-related or output-related while the economic indicators can be financial or employee-related (Krajnc and Glavic 2003). The purpose of any of these indicators is to reflect the wholeness of the system while displaying the interaction among its subsystems (Krajnc and Glavič 2003).

The next section of the paper presents an overview of the tea industry on which ecoinnovation was experimented.

\section{Industry setting - tea industry}

In this case study, the tea industry was selected for several reasons. First, tea (Camellia sinensis) is the manufactured drink most consumed in the world (Chang 2015; Owuor et al. 2011). It is currently grown in more than 35 countries, providing a valuable source of employment and export earnings, particularly for developing countries (Forum for the Future 2014). China, India, Kenya and Sri Lanka are the world's largest tea producing and exporting countries (Forum for the Future 2014). Second, the tea industry has recently faced many challenges mainly due to the accelerated escalation of the cost of production, drop in world tea prices, severe debilitation of tea bushes and lack of productivity improvements (International Tea Committee (ITC) 2015; Oxford Business Group 2016). Eco-innovation is of significant importance at a time when the tea industry considers resource constraints and competition for land and productivity 
as two of the ten challenges the industry is facing (Forum for the Future 2014). Third, since one of the co-authors is a tea planter by profession, the tea industry provided us the access and opportunity to carry out this experimental case study on a commercial tea garden while measuring its impact over a period of time.

\section{Technical problem}

Under commercial conditions, a tea plant is trained into a dwarf and dense bush of between 0.6 and $1.3 \mathrm{~m}$ in height with spread branches purely for the convenience of harvesting the tender tea shoots ${ }^{4}$ (Kumar et al. 2015; Selvendran 1970; Tea Research Association (TRA) 2015). With the frequent harvesting of emerging tender shoots, usually on a weekly basis, the tea bush is subjected to continuous trimming over a period (Ravichandran 2004). This results in a gradual display by the plant of the "hedge-roweffect" ${ }^{\text {"5 }}$ whereby large numbers of tiny low quality shoots are formed (refer Fig. 1).

Therefore, the quality of the tea flush is in a state of gradual decline over time. Further, harvesting operations become difficult too as the shoot size gets smaller with the increased bush height. Thus, commercial tea bushes are subjected to periodic pruning almost every 3-5 years in order to rejuvenate the tea bushes with a high quality succulent flush. However, this periodic pruning process creates several economic, environmental and social issues:

- A sudden loss of bush canopy brings down the crop production to zero level (Ravichandran and Parthiban 1998a; Selvendran 1970) (refer Figs. 2 and 3).

- The conventional way of training/spreading tea bushes by "conventional tipping"6 after pruning has limitations of expanding the bush frames. Thus it takes more than 36-42 months to fully re-develop the canopy cover.

- The exposure of the soil is directly affected by several biotic and abiotic forces of nature, including sunlight, rainfall, wind and animal action with this sudden opening of the bush-canopy due to pruning. This process further results in severe soil degradation and wastage of other free natural resources such as sun light and rain water (refer Fig. 3).

- High operational costs are entailed particularly because of excessive growth of weeds on exposed ground resulting in an amplified demand for frequent weed

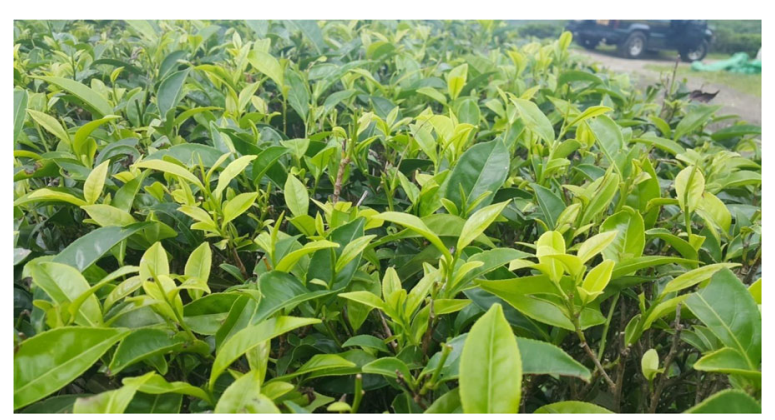

Fig. 1 Tea bushes subjected to hedge-row-effect over time. Due to this hedge-row-effect, the formation of clustered tiny shoots causes difficulty in harvesting 


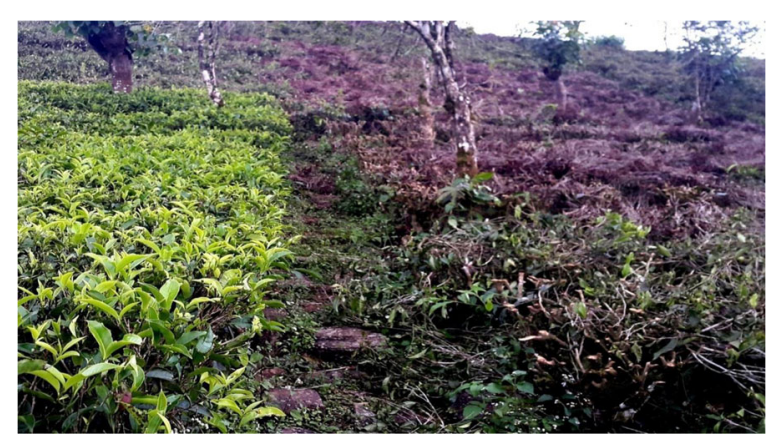

Fig. 2 Periodic pruning of commercial tea. The right hand side of the picture shows how pruning causes a sudden loss of bush-canopy in tea gardens

control and other agricultural inputs such as fertilizer, pest and disease control, etc. (Yamada et al. 2009).

- Escape of agricultural inputs such as fertilizer, weedicide and other chemicals can contaminate the atmosphere and water sources of the communities and employees (Chauhan and Singhal 2006).

- Reduction in crop yield after pruning reduces the income of the employees and families as their wages are mainly dependent on the quantity of tea plucked.

Finding innovative ways of improving crop productivity during this pruning process while minimizing the waste of inputs is therefore a vital requirement for ensuring the future of the tea industry.

\section{Technical solution - the eco-innovation}

A well spread bush frame is highly beneficial to crop species like tea since the active production area is the bush-canopy of the tea plant and the immature shoots (the bud and two leaves) are the commercially important part of the plant. Therefore, a quick re-establishment of the tea canopy following pruning is of utmost importance. The eco-innovation method followed is explained in the following paragraph.

Generally, pruned tea bushes are ready for the first harvest by 90 days from pruning if the growing conditions are favourable. Conventionally, the tea bushes are grown to a level parallel to the ground at the first harvest itself forming a plucking table. This eco-

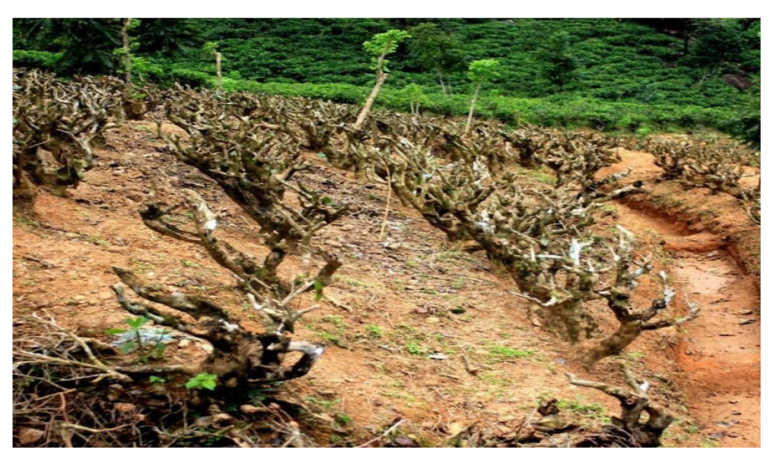

Fig. 3 Tea fields 3 weeks after pruning. Generally, pruned branches are removed and thorough weeding is done after pruning. This causes complete exposure of the ground to natural forces 
innovative method (which we call Strip Spreading of Tea Bushes [SSTB]) allows the recovery of tea bushes from pruning to grow up to 120 days without harvesting. Thereafter, the growing shoots are spread radially exposing them more to sunlight. This radial spreading of shoots is done using tight parallel stripes arranged along the tea rows. Here, the branches are temporarily held by the tight parallel stripes allowing them to shoot up more. Therefore, this process allows tea bushes to grow larger compared to conventional tipping (refer Figs. 4, 5 and 6). Since one of the co-authors who invented this idea is in the process of obtaining the patent for this innovation, there are certain technical matters that can't be disclosed in the paper as at now. Recently, in recognition of this innovation, a co-author of the paper was adjudged the 2016 Blue Economy Concept Sector Winner of the Dilmah Conservations 2016 - Merrill J. Fernando EcoInnovation Awards. ${ }^{7}$

The concept of SSTB instead of Conventional Tipping of Tea Bushes (CTTB) after pruning offers the opportunity for early re-establishment of the canopy by engineering existing bush frames of tea, thus resolving many of the negative factors inherent in the present practice of periodic pruning.

\section{Method}

In order to operationalize this eco-innovation, an experimental case study was launched in 2015 at Hapugastenne Tea Garden, (lat $6.872^{\circ}$, lon $80.530^{\circ}$ ) in Maskeliya, Sri Lanka. The purpose was to ascertain and compare the regeneration of the bush frame by the stripe-spreading method (treatment) against the current conventional post-pruning practice of tipping (control). Randomly selected five lots of $10 \mathrm{mx} 20 \mathrm{~m}$ experimental plots in clusters of four pairs of replicates were established in vegetatively propagated (VP) tea fields, aged between 25 and 54 years since planting at three different elevation ranges. The experimental blocks and the plots were located on similar terrain, parallel orientations and also shade conditions too that were almost alike.

Recovering tea bushes after pruning were allowed to grow up to 120 days and then, a radial spread of shoots was done using tight parallel stripes arranged along the tea rows instead of tipping in the treatment plots, while practising conventional tipping in the control plots declared adjoining them with the same cultivar of tea (refer Fig. 6). Both experimental and control plots were treated alike with all other agricultural practices. Data was collected methodically at regular intervals, but for the purpose of analysis they are presented for periods of 4, 6, 10 and 14 months.

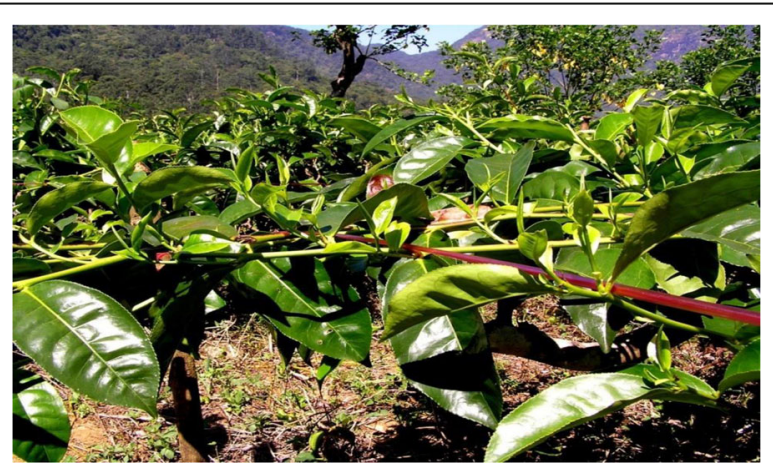

Fig. 4 Initiation of SSTB Method @120-140 days from pruning 


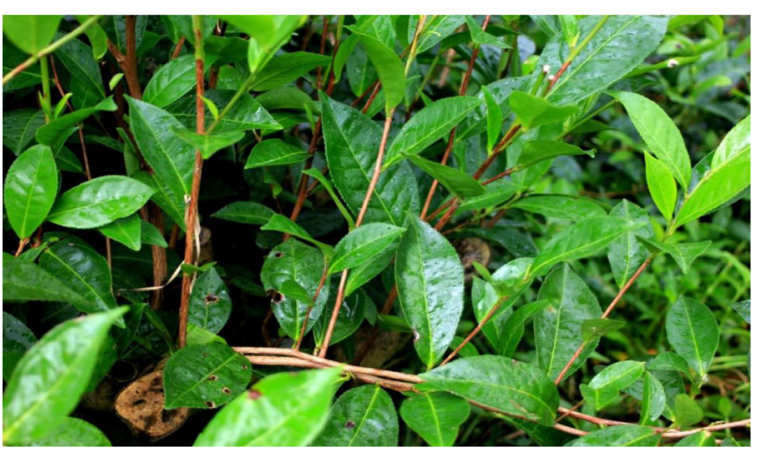

Fig. 5 SSTB @ 160-180 days. SSTB quickly allows developing a greater bush canopy cover

The same workers were employed in both treatment and control plots. Instruments such as weighing scales and spray tanks used for foliar spraying were regularly calibrated. The measurements and records maintained by the plantation company were regularly audited by internal, external and statutory audit teams independently after verifying and confirming all estate records.

Since the bush canopy area coverage was the main aspect of the study, plot area was taken as a parameter. Comparatively much larger trial plots were selected in order to minimize noise and improve the precision of results and thus the credibility of the study. Measurements were taken plot-wise. This experiment was done in a VP tea where all tea bushes in a plot are descendants of a single mother plant and hence genetically alike. Any variations observed would have been due to varying environmental conditions.

In analyzing the results, some of the indicators such as weeding cost and tea output were extracted from the records maintained by the plantation company while other measures such as foliar spray waste and canopy area were measured specifically for the study by independent third party personnel under the supervision of the researchers. As mentioned at the outset, this paper presents some of the initial outcomes of this experimental study. Hence, there are aspects which have not been covered in this paper owing to practical limitations. Even though it is too early to identify the long-term outcomes of this experiment, yet the authors are of the view that the trend highlighted in this results would continue and provide useful insights for measuring the impact of eco-innovations.

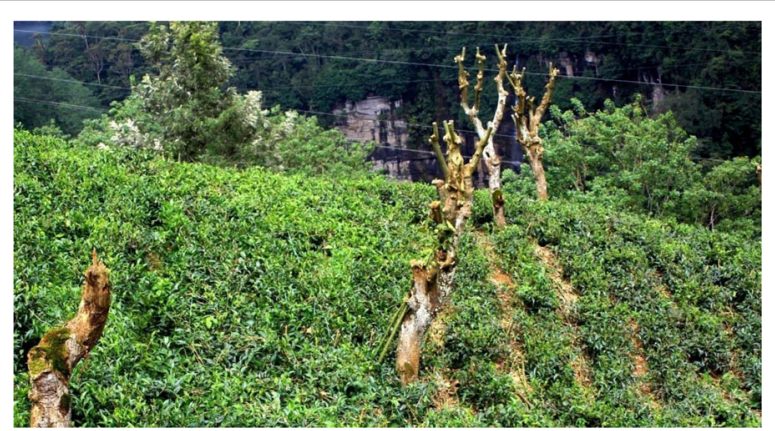

Fig. 6 Adjoining treatment and control plots. SSTB (left) and CCTB (right) after 180 days from pruning. The picture clearly shows the difference in the development of canopy 


\section{Analysis and results}

The viability of the eco-innovation (i.e., SSTB approach) is assessed mainly from economic and environmental perspectives with a variety of monetary and physical EMA measures as suggested by Burritt et al. (2002). However, the study also captures some social measures as well. All these measures were based on industry norms. Hence the following section is arranged under three sections: a) economic perspective, b) environmental perspective, and c) social perspective.

\section{The economic perspective}

The economic perspective was measured mainly through a combination of monetary and physical sustainability information by focusing on productivity (measured in terms of crop yield); foliar spray wastage and weeding cost (refer Table 1). The tea yield is an output as well as a core measure while the foliar spray wastage and weeding cost are supplemental and input indicators.

There was an initial expenditure of labour (Rs.688) and material cost (Rs. 1288) per plot in SSTB when training the tea bushes by spreading branches. Initially, after around 4 months from pruning, there was a setback seen in the crop harvested from treatment plots since they were rested without plucking. Therefore, control plots showed a comparatively higher crop up to that time. However, this situation started to change as spread branches started sprouting and yielding crop at an increasing rate of around 160 days onwards (i.e. after 5 months). Early costs incurred on training of tea bushes was paid back in the next few months in the form of savings made on other inputs such as weed control, fertilizer minimizing wastage and also by the crop increment shown in treatment plots. However, the authors of this study are of the view that it is too early to go ahead with a cost benefit analysis at this point, since many more persistent benefits are yet to come and need to be evaluated over the next few years to complete one full pruning cycle. The treated area reached a 34\% higher yield level compared to the

Table 1 Economic analysis of the control vs. treatment plots

\begin{tabular}{|c|c|c|c|c|}
\hline & Time (in months) & Treatment [SSTB] & Control [CCTB] & $\%$ difference \\
\hline \multirow[t]{4}{*}{ Made tea yield (kg) } & 4 & 0 & 90 & \\
\hline & 6 & 621 & 462 & $+34 \%$ \\
\hline & 10 & 1272 & 923 & $+38 \%$ \\
\hline & 14 & 2148 & 1509 & $+42 \%$ \\
\hline \multirow[t]{4}{*}{ Foliar spray wastage (\%) [Note ${ }^{a}$ ] } & 4 & $60 \%$ & $60 \%$ & $0 \%$ \\
\hline & 6 & $10 \%$ & $40 \%$ & $-75 \%$ \\
\hline & 10 & $6 \%$ & $30 \%$ & $-80 \%$ \\
\hline & 14 & $2 \%$ & $25 \%$ & $-92 \%$ \\
\hline \multirow[t]{4}{*}{ Cost of weeding (Rs.) [Note b] } & 4 & 7050 & 7050 & $0 \%$ \\
\hline & 6 & 10,460 & 15,292 & $-32 \%$ \\
\hline & 10 & 22,410 & 34,200 & $-34 \%$ \\
\hline & 14 & 28,120 & 43,260 & $-35 \%$ \\
\hline
\end{tabular}

${ }^{a}$ This is the waste of agricultural inputs when applied directly as watery droplets on crop foliage expecting a quick response. This was measured by subtracting the canopy cover of the tea bushes from the total area of the spray application ${ }^{\mathrm{b}}$ This represents the cost herbicide chemicals and labour employed for manual weeding. The mix of these two cost components varies with time and also with the condition of the field. Hence an average figure has been used in this study 
control area by 6 months from pruning and continued the performance by passing 38 and $42 \%$ higher levels as against the control area (refer Table 1). Hence the treatment plots quickly overcame the problem of low crop production due to the loss of bushcanopy, which is a problem of pruning as highlighted by Selvendran (1970) and Ravichandran and Parthiban (1998a).

The next physical EMA measure observed in the study, i.e., the wastage of foliar spray inputs, was minimal in the treated plots due to a larger and thicker bush-canopy area (refer Figs. 7 and 8). However, a large amount of foliar spray was wasted and reached ground level promoting weed growth in the control plots due to exposed ground resulting from smaller bush-canopy. As shown in Table 1, the foliar spray wastage was reduced to around a $2 \%$ level from the original $60 \%$ over the period in treatment plots whereas the same in the control plots was reduced only to $25 \%$.

The third EMA measure, the cost of weeding, showed a reduction in the treatment plots due to the establishment of the bush-canopy covering the ground. A growth of herbicide-tolerant creeper weeds was observed in these plots; they needed to be removed manually from the field. However, overall weeding cost was on a downward trend in the treatment plots when compared to the control plots (refer Table 1). The weeding cost gradually dropped by 32 to $35 \%$ in the treatment area as against the control area, from the 6th month to the 14th month respectively from pruning. As Channaveera et al. (2011) note, in the control plots the use of weedicide is not only ecologically undesirable but has also driven up the input costs of tea production. Moreover, this weedicide does not ideally fall on the target and becomes degraded completely to harmless compounds. They drift into the environment affecting the eco system (Chauhan and Singhal 2006). Hence, the treatment plots clearly demonstrate a notable improvement not only from an economic perspective but also from an ecological perspective. Although not quantified in this study, the use of weedicides to control undergrowth in tea estates can negatively affect local plant and animal biodiversity (Sudhi 2013).

\section{Environmental perspective}

The use of core environmental measures such as energy, water or waste is not relevant to this study. Hence, the authors had to search for supplemental measures. The environmental perspective of the eco-innovation was therefore assessed through physical EMA information by using the canopy area and ground cover (refer Table 2). Instead of quantifying

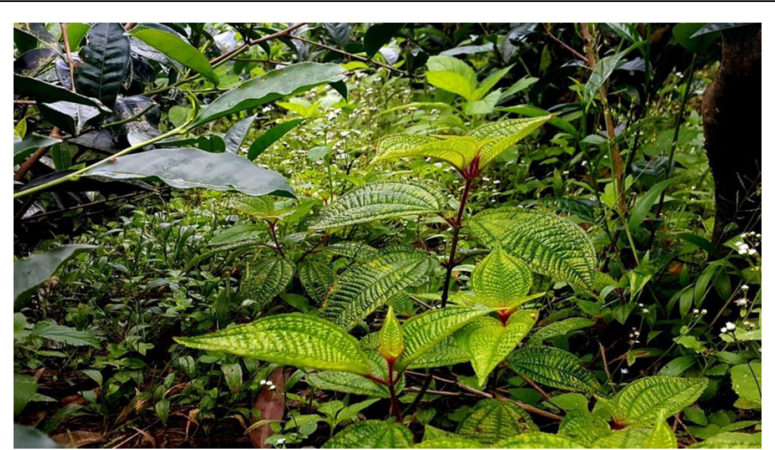

Fig. 7 Ground beneath at 08 months from pruning under control plots. The weed growth on exposed ground on tea inter-rows is in the range of 1000-1450 weed plants per $\mathrm{m}^{2}$. This, in turn, propagates chemical tolerant harmful weeds for tea 


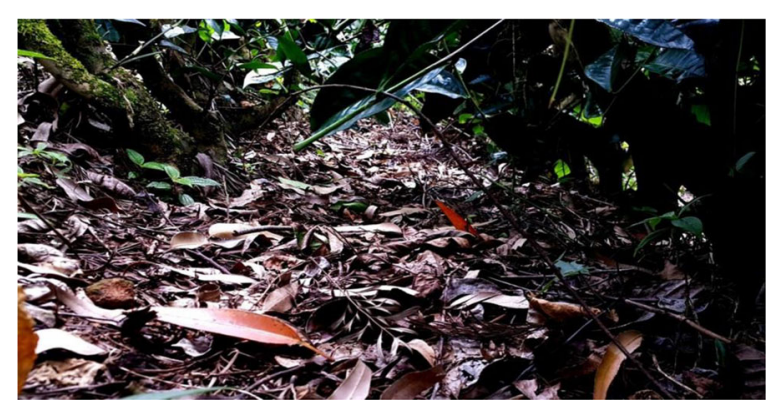

Fig. 8 Ground beneath at 08 months from pruning under treatment plots. The canopy cover of a tea bush is well developed optimizing resource usage while minimizing the growth of weeds

carbon storage parameters the canopy area of a bush and ground cover were taken here since they are directly and broadly linked with resource use efficiency and productivity in real terms in applied agriculture. It also offers a more manageable measure to start with when compared with complex carbon storage indicators. These selected measures provide additional plant biomass while absorbing the atmospheric $\mathrm{CO}_{2}$ emissions, representing a reduction in a factor contributing to climate change (Harris 1992).

It was observed that in the treatment area, bush canopies were developed to $0.5 \mathrm{~m}^{2}$ by 04 months from pruning, forming 40 to 50\% (average 45\%) ground cover overlapping branches with neighbouring tea bushes. This was further developed into an overall 98\% ground cover in the treatment plots 14 months after pruning. In contrast, the bushes in the control plots were developed only to $0.45-0.77 \mathrm{~m}^{2}$ canopy area whilst achieving $39-70 \%$ ground cover within the same period.

As Table 2 shows, the tea bushes in the treatment plots has the ability to develop a $245 \%$ larger canopy area on average when compared to control plots. Undoubtedly, this increases the natural resource use efficiency of tea bushes such as sunlight, moisture and reduced foliar spray wastage. It also prevents erosion and degradation of soil, enabling the healthy growth of the tea bush. As highlighted by Owuor et al. (2011), soil is an essential environmental factor that affects the growth of tea plants and the SSTB method improves the soil of the tea plantations. Further, this concept largely contributes to minimizing environment pollution in general and improving the quality and quantity of drinking water supplied to the country for drinking, domestic and irrigation purposes.

Table 2 Environmental analysis of the treatment vs. control plots

\begin{tabular}{lcccc}
\hline & Time (in months) & Treatment [SSTB] & Control [CCTB] & \% difference \\
\hline Canopy area of a bush $\left(\mathrm{m}^{2}\right)$ & 4 & 0.53 & 0.45 & $118 \%$ \\
& 6 & 1.80 & 0.73 & $247 \%$ \\
& 10 & 1.84 & 0.76 & $242 \%$ \\
Ground cover (\%) & 14 & 0.77 & $240 \%$ \\
& 4 & $45 \%$ & $39 \%$ & $115 \%$ \\
& 6 & $90 \%$ & $40 \%$ & $225 \%$ \\
& 10 & $94 \%$ & $56 \%$ & $168 \%$ \\
& 14 & $98 \%$ & $70 \%$ & $140 \%$ \\
\hline
\end{tabular}




\section{Social perspective}

As discussed in the extant literature, selection of suitable social measures was difficult. The social perspective of the eco-innovation was measured by using the income generated for the workers from improved land productivity. As shown in Table 1, the increased productivity of 34\% (from 6 months onwards) resulted in an equivalent amount of additional income for the workers. Also, there were many benefits that are difficult to quantify such as soil conservation, improved the water sources and the quality of water for the workers and community, in general. As elaborated above, SSTB method suppresses the weed growth (as given in Figs. 7 and 8) by efficient trapping of both sunlight and foliar sprays while minimizing the chance of reaching such resources down to the emerging weeds on the ground. Thus, chemical weeding is not required in SSTB after 06 months from pruning and any emerging odd weeds could be managed by periodic spot weeding. Therefore, detrimental impacts of weedicide chemicals on the sprayers, workers and community could be eliminated by SSTB. Some of these positive impacts are presented in Table 3.

Nowadays there is increased concern about the use of weedicides that may lead to their residues affecting the food chain causing harm to human beings and animals (Chauhan and Singhal 2006). Hence under the SSTB method, due to the low use and escape of agricultural inputs (especially weedicides) from the farming system, the environment would become less hazardous to humans and animals.

\section{Discussion}

The above analysis presents some interesting points for discussion. The results show that this process of eco-innovation improves the existing tea pruning process by reducing the environmental impact while improving societal and economic benefits. Further, this innovative method (i.e. SSTB over CCTB) improves land productivity and agricultural resource utilization, two major problems envisaged by Forum for the Future (2014) in its "tea 2030 vision". SSTB actually lowers the frequency of pruning and improves the land productivity and resource use efficiency of tea plantations, thus lowering the operational cost and unit cost of production. Hence this method leads to sustainable agricultural practices by improving the ability of the agricultural systems to maintain crop productivity in the long run while at the same time producing environmental and social benefits (Francis et al. 1987; Gafsi et al. 2006; Lichtfouse et al. 2009; Peiris and Gunarathne, 2015). These types of investments do not require substantial capital investment or deployment of advanced technology or skilled labour. Hence, these "non-technological" innovations (Organisation for Economic Co-operation and Development (OECD) 2009) with minimum capital, technological or labour investments can be used to reduce the environmental and social impact while achieving

Table 3 Some benefits of eliminating chemical weeding on SSTB

\begin{tabular}{ll}
\hline Aspects & Quantification of the impact \\
\hline $\begin{array}{l}\text { Reduction of the exposure of sprayers to } \\
\text { chemical weeding }\end{array}$ & $\begin{array}{l}12 \text { man days of chemical weeding per } \\
\text { hectare [Note] }\end{array}$ \\
$\begin{array}{l}\text { Use of weedicide chemicals } \\
\text { - Diuron }\end{array}$ & $3.6 / \mathrm{kg}$ per hectare * 3 rounds \\
- Glufocinate Ammonium & $4.5 / 1$ per hectare *3 rounds \\
\hline
\end{tabular}

This was calculated as 4 man days of sprayers per hectare per round of chemical weeding* 3 rounds during the period 
economic benefits. Since most of the top tea producing countries are developing countries with limited access to advanced technology and major constraints on large capital investments, these types of innovations have the potential to improve productivity with minimum investments. From another dimension, this study supports the "lean-green" concept in the agricultural industry since it uses less agricultural inputs to improve financial performance while preventing environmental burdens and contributing to social equity (Abreu et al. 2017; Dües et al. 2013; Rothenberg et al. 2001). This eco-innovation was not initially intended (Carrillo-Hermosilla et al. 2010; Horbach et al. 2012) to bring about environmental or social improvements but to reduce crop loss in the pruning cycle. However, the synergistic benefits of lean by way of using less waste of inputs and better use of land has derived positive results in the economic, environmental and social spheres. This suggests that managers broaden their scope of analysis beyond the economic dimensions to incorporate the wider environmental and social benefits when assessing eco-innovations. It will also make "environmentally friendly investments" more acceptable (Environmental Protection Agency (EPA) 1995).

In this case study several indicators were used to assess the impact of eco-innovation. In order to capture the multidimensionality of sustainability these measurements should consider the economic, social and environmental aspects (Pope et al. 2004). Due to the diverse nature of operations in different industries, it is difficult to have a standardized set of indicators to measure the impact of sustainability initiatives (Krajnc and Glavič 2003; Veleva and Ellenbecker 2001). Although the extant literature states that the core indicators are common for any industry (Veleva and Ellenbecker 2001), the use of these indicators is even difficult in the plantation agriculture industry which covers a wide range of crops such as tea, palm oil, cocoa, rubber and coffee. This makes the use of supplemental indicators essential (Veleva and Ellenbecker 2001). However, the use of supplemental indicators makes the inter-industry comparison of ecoinnovations difficult as there are few common indicators. Further, we do not suggest that the intra-industry comparison is somewhat easier. Owing to the differences in many factors such as soil condition, weather patterns and labour practices, there will be difficulties in making intra-industry comparisons also. These differences call for the application of additional indicators. However, given the need for a manageable number of indicators that are simple and easy to apply (Krajnc and Glavič 2003), the use of multiple indicators could render the measurement process of eco-innovations complex and unmanageable. Hence, the selection of sustainability indicators to assess the impact of eco-innovations necessitates a trade-off between accuracy and manageability. On the other hand, the use of generic measures such as carbon storage can be too complex. This can be an important constraint for many small and medium sector enterprises in developing countries where the plantation agriculture industry plays a key role.

Echoing a similar challenge that prior researchers have encountered, the present researchers too had a problem in selecting the appropriate sustainability indicators for the assessment of social dimension in eco-innovations. This is mainly because, so far, the social side of sustainability and hence the social sustainability indicators have received little attention (Dillard et al. 2009; Gunarathne et al. 2016; Krajnc and Glavič 2003; Von Geibler et al. 2006). The social perspective of sustainability is intangible and qualitative in nature and lacks consensus on relevant criteria (Von Geibler et al. 2006). 
This calls for innovation in accounting (Schaltegger et al. 2017) to develop indicators and mechanisms to assess the various facets of sustainable development.

Problems associated with measuring sustainable development (Hamilton and Atkinson 2006; Boggia and Cortina 2010), corporate sustainability performance (Escrig-Olmedo et al. 2017), and developing suitable indicators (Krajnc and Glavič 2003) are common to the assessment of eco-innovations. Hence this case study, while highlighting the difficulties in measuring impact of eco-innovations, emphasizes the need for the further development of sustainability indicators. Without proper assessment it is difficult to gauge how far the intended outcomes have been reached. As Krajnc and Glavič (2003) suggest “...to cope with the complexity of sustainability-related issues for different systems, the indicators have to reflect the wholeness of the system as well as the interaction of its subsystems (p. 281)". We used only simple and easy-to-implement indicators, but when a company advances it is necessary to move towards more complex indicators (Escrig-Olmedo et al. 2017; Krajnc and Glavič 2003). Perhaps, the way forward can be the development of fuzzy multi-criterion decision-making (MCDM) methods (Escrig-Olmedo et al. 2017; Boggia and Cortina 2010; Krajnc and Glavič 2003) to assess the impact of eco-innovations. On the other hand, most of the impact of eco-innovations are long term, particularly in the plantation agriculture industry. Therefore, in addition to the selection of a set of indicators there is the challenge to determine the suitable time frame for the assessment. This highlights the challenges faced in the development of indicators considering the main dimensions of sustainability indicators, i.e. unit of measurement, type of measurement, tracking period and measurement boundary (Krajnc and Glavič 2003).

Our case study further highlights the difficulties in carrying out a priori cost-benefit analysis in terms of an investment appraisal (Drury 2009; Environmental Protection Agency (EPA) 1995) since eco-innovations would involve capital expenditure. This difficulty could arise owing to several reasons. One reason is the difficulty in monetizing some of the environmental and social impact. As explained in the previous paragraph, another issue lies with the selection of the suitable indicators and the time period. These issues converge to highlight the typical problems associated with capital budgeting (refer Rossi 2014; Drury 2009; Brounen et al. 2004). Another interesting issue that makes a priori cost benefit analysis difficult is the nature of eco-innovations. As most eco-innovations are unintentional (Carrillo-Hermosilla et al. 2010; Horbach et al. 2012; Organisation for Economic Co-operation and Development (OECD) 2009) an entity would only realize its potential once the innovation is carried out. Hence what is possible is post-completion sustainability investment appraisal only. According to Burritt et al.'s (2002) comprehensive framework, this leads a company to apply ex-post investment assessments which should be done both in physical and monetary terms.

\section{Conclusions and directions for further research}

The purpose of this case study was to contribute to the body of knowledge on the assessment of eco-innovations by carrying out an experimental case study in the agricultural plantations industry. Innovations mainly aimed at enhancing economic gains can have accidental impact on the environment. However the assessment of the impact of these eco-innovations is the challenge. Since due to the underdeveloped theoretical and methodological approaches to analyze these benefits (Rennings 2000; Peiris and Gunarathne, 2015), the study used the triple bottom line approach. In doing so 
physical and monetary sustainability information was used (Burritt et al. 2002, International Federation of Accountants (IFAC) 2005) to quantify these impacts. Yet there are many potential impacts that were not captured in the present paper. It is only when these impacts are considered that the full benefit of ecoinnovations can be evaluated. This case study reveals the difficulty in having a standardized set of indicators to measure the impact of eco-innovations owing to the multidimensionality of sustainability. Further, this case study emphasizes that the problems associated with measuring sustainability are common to the assessment of eco-innovations as well. Hence there is a need for further development of sustainability indicators to make inter and intra industry comparisons of the ecoinnovations meaningful. The way forward would be to adopt broad sustainability indicators that represent the wholeness of the system while capturing the long term impacts.

The findings of this case study can have several limitations. Since the study was carried out in a particular tea field with specific characteristics there is a need to replicate the study under different conditions and for different types of perennial crops. This study only presents the outcomes of this study covering 14 months. However, in the agricultural plantation sector there are long-term impacts across a variety of aspects. This creates a need to identify the benefits or impacts over longer time periods. In this study some of the broader benefits and/or different aspects were not measured due to various practical difficulties. For instance, many scholars have drawn attention to the quality of tea after pruning (see Grice 1985; Owuor et al. 1990; Ravichandran 2004; Ravichandran and Parthiban 1998b). However, the study did not observe some of the parameters as the purpose of this paper was to present the early results of the experiment. Hence it would be necessary to investigate these aspects in future studies.

\section{Endnotes}

${ }^{1}$ Plantation agriculture is a form of commercial farming where crops are grown for profit (Geography 2012). Some of the main plantation crops include beverages (such as tea, coffee and cocoa), rubber, oil palm, cotton, beverages (such as coffee, tea and cocoa), fruits (such as pineapples and bananas), rubber, oil palm, cotton, and sugarcane.

${ }^{2}$ We refer to the "non-technical" innovations as the type of innovation that does not require extensive $\mathrm{R} \& \mathrm{D}$ expenditure, additional capital or training of labour.

${ }^{3}$ EMA is a decision support tool when organizations follow various environmental management strategies/practices (Bennett et al. 2002). It uses a wide array of accounting tools and techniques that provide physical and monetary information for decision makers.

${ }^{4}$ Growing flush containing a leaf bud and 2-3 immature leaves, without hard parts such as woody stalk and fibre.

${ }^{5}$ Formation of clustered shoots with tiny leaves as a thick layer on hedges over time, due to continuous trimming.

${ }^{6}$ Conventional tipping refers to trimming of growing shoots of recovering tea bushes from pruning, to a level parallel to the ground, to obtain a green carpet surface for the convenience of harvesting. 
${ }^{7}$ This is an award scheme initiated by Dilmah Conservation, a project of the world famous Sri Lankan tea brand Dilmah, to promote sustainable environmental and social development initiatives.

\section{Acknowledgements}

The authors are grateful for helpful comments and suggestions from the anonymous reviewers as well as conference participants at the 2016 Environmental and Sustainability Management Accounting Network Conference in Asia Pacific (EMAN-AP), Korea.

\section{Funding}

There is no specific funding applicable for this project.

\section{Authors' contributions}

Both authors contributed equally in the project (50\%:50\%). Both authors read and approved the final manuscript.

\section{Competing interests}

We declare that we do not have any competing interest.

\section{Publisher's Note}

Springer Nature remains neutral with regard to jurisdictional claims in published maps and institutional affiliations.

\section{Author details}

${ }^{1}$ Department of Accounting, University of Sri Jayewardenepura, Nugegoda, Sri Lanka. ${ }^{2}$ Griffith Business School, Griffith University, Gold Coast, Australia. ${ }^{3}$ Hapugastenne Estate, Maskeliya Plantations PLC, Maharagama, Sri Lanka.

${ }^{4}$ Postgraduate Institute of Science, University of Peradeniya, Peradeniya, Sri Lanka.

Received: 4 January 2017 Accepted: 20 July 2017

Published: 7 August 2017

\section{References}

Abreu MF, Alves AC, Moreira F (2017) Lean-Green models for eco-efficient and sustainable production. Energy https:// doi.org/10.1016/j.energy.2017.04.016. Accessed 28 Apr 2017

Ariza C, Rugeles L, Saavedra D, Guaitero B (2013) Measuring Innovation in Agricultural Firms: A Methodological Approach. Electron J Knowl Manag 11(3):185-198

Arundel A, Kemp R (2009) Measuring eco-innovation. United Nations University - Maastricht Economic and social Research and training centre on Innovation and Technology, The Netherlands

Bennett MJ, Bouma J, Walters T (2002) Environmental Management Accounting: Informational and Institutional Developments. Kluwer, Dordrecht

Berdegue JA, Escobar G (2002) Rural Diversity, Agricultural Innovation Policies and Poverty Reduction. Agricultural Research \& Extension Network, Network Paper No. 122

Boggia A, Cortina C (2010) Measuring sustainable development using a multi-criteria model: A case study. J Environ Manag 91(11):2301-2306

Bossle BM, De Barcellos MD, Vieira LM (2016) Why food companies go green? The determinant factors to adopt eco-innovations. Br Food J 118(6):1317-1333

Brounen D, De Jong A, Koedijk K (2004) Corporate Finance in Europe: Confronting Theory with Practice. Financ Manag 33(4):71-101

Burritt R, Hahn T, Schaltegger S (2002) Towards a comprehensive framework for environmental management accounting: links between business actors and environmental management accounting tools. Aust Account Rev 12(2):39-50

Carrillo-Hermosilla J, del Río P, Konnola T (2010) Diversity of eco-innovations: reflections from selected case studies. J Clean Prod 18:1073-1083

Chang K (2015) World Tea Production and Trade: Current and Future Development. Food and Agriculture Organization of the United Nations, Rome

Channaveera H, Lokeshaa LB, Hugara JB, Deshmanyab GSB (2011) Impact of MGNREGA on Input-use Pattern, Labour Productivity and Returns of Selected Crops in Gulbarga District, Karnataka. Agric Econ Res Rev 24:517-523

Chauhan RS, Singhal L (2006) Harmful Effects of Pesticides and their Control through Cowpathy. Int J Cow Sci 2(1):61-70

Diederen P, Meijl H, Wolters A, Bijak K (2003) Innovation Adoption in Agriculture: Innovators, Early Adopters and Laggards. Cah D'économie Sociol Rurales 67:29-50

Dillard J, Dujon V, King MC (2009) Introduction. In: Dillard J, Dujon V, King MC (eds) Understanding the Social Dimension of Sustainability, Routledge, New York, pp 1-14

Drury, C. (2009). Management Accounting for Business Andover: Cengage Learning

Dües CM, Tan KH, Lim M (2013) Green as the new Lean: how to use Lean practices as a catalyst to greening your supply chain. J Clean Prod 40:93-100

Environmental Protection Agency (EPA) (1995) An introduction to environmental accounting as a business management tool: Key concepts and terms. EPA, Washington

Escrig-Olmedo E, Muñoz-Torres MJ, Fernández-Izquierdo MÁ, Rivera-Lirio JM (2017) Measuring Corporate Environmental Performance: A Methodology for Sustainable Development: Measuring Corporate Environmental Performance. Bus Strateg Environ 26(2):142-162

Feder G, Just R, Zilberman D (1985) Adoption of Agricultural Innovations in Developing Countries: A Survey. Econ Dev Cult Chang 33(2):255-298

Forum for the Future (2014) The Future of Tea a Hero Crop for 2030. Tea 2030 Steering Group, UK 
Francis CA, Sander D, Martin A (1987) Search for a sustainable agriculture: reduced inputs and increased profits. Crops Soils Manag 39:12-14

Gafsi M, Legagneux B, Nguyen G, Robin P (2006) Toward sustainable farming systems: effectiveness and deficiency of the French procedure of sustainable agriculture. Agric Syst 90:226-242

Geography (2012) Plantation Agricultur. Available at http://thestudyofearth.blogspot.com.au/2012/03/plantation-agriculture. html. Accessed 4 Dec 2016

Grice WJ (1985) Shoot growth of Indian hybrid seedling tea in all stages of three-year-cycle. Tea Research Foundation of Central Africa. Q Newsl 80:4-9

Gunarathne N, Samudrage D, Wijesinghe DN, Lee KH (2016) Fostering social sustainability management through safety controls and accounting: A stakeholder approach in the mining sector. Account Res J 29(2):179-197

Hamilton K, Atkinson G (2006) Wealth, welfare and sustainability: advances in measuring sustainable development. Edward Elgar, Northampton; Cheltenham

Han JK, Kim N, Srivastava RK (1998) Market Orientation and Organizational Performance: Is Innovation a Missing Link? J Mark 62(4):30-45

Harris RW (1992) Root-Shoot Ratios. J Arboric 18(1):39-42

Horbach J, Rammer C, Rennings K (2012) Determinants of eco-innovations by type of environmental impact - The role of regulatory push/pull, technology push and market pull. Ecol Econ 78:112-122

International Federation of Accountants (IFAC) (2005) International Guidance Document: Environmental Management Accounting. IFAC, New York

International Tea Committee (ITC) (2015) Annual bulletin of statistics. ITC, London

Kammerer D (2009) The effects of customer benefit and regulation on environmental product innovation., Empirical evidence from appliance manufacturers in Germany. Ecol Econ 68:2285-2295

Keeble JJ, Topiol S, Berkeley S (2003) Using indicators to measure sustainability performance at a corporate and project level. J Bus 44(2):149-158

Kemp R, Pearson P (2008) Final Report MEl Project about Measuring Eco innovation: Deliverable 15 of MEl Project (D15)

Krajnc D, Glavič P (2003) Indicators of sustainable production. Clean Techn Environ Policy 5(3):279-288

Kumar R, Bisen JS, Singh M, Bera B (2015) Effect of Pruning and Skiffing on Growth and Productivity of Darjeeling Tea (Camellia Sinensis L.) Int J Tech Res Appl 3(3):28-34

Lichtfouse E, Navarrete M, Debaeke P, Souchere V, Alberola C, Menassieu J (2009) Agronomy for sustainable agriculture. A Review. Agron Sustain Dev 29(1):1-6

Marin G, Lotti F (2017) Productivity effects of eco-innovations using data on eco-patents. Ind Corp Chang 26(1):125-148

Negny S, Belaud J, Robles C, Reyes R, Ferrer B (2012) Toward an eco-innovative method based on a better use of resources: application to chemical process preliminary design. J Clean Prod 32:101-113

Ongong J, Ochieng A (2013) A Innovation in the Tea Industry: The Case of Kericho Tea, Kenya. Glob J Manag Bus Res 13(1):53-67

Organisation for Economic Co-operation and Development (OECD) (2005) Oslo Manual: Guidelines for Collecting and Interpreting Innovation Data, third edn. OECD, Paris

Organisation for Economic Co-operation and Development (OECD) (2009) Sustainable manufacturing and eco-innovation. Framework, practices and measurement, Synthesis report. OECD, Paris

Owuor PO, Kamau DM, Kamunya SM, Msomba SW, Uwimana MA, Okal AW, Kwach BO (2011) Effects of genotype, environment and management on yields and quality of black tea. Genet. Biofuels Local Farm. Systems. Sustain Agric Rev 7:277-307

Owuor PO, Obaga SO, Othieno CO (1990) Effects of altitude on chemical composition of black tea. J Sci Food Agric 50:9-17

Oxford Business Group (2016) Growth prospects for Sri Lanka's tea industry. Available at http://www.oxfordbusinessgroup. com/news/growth-prospects-sri-lanka\%E2\%80\%99s-tea-industry. Accessed 30 Oct 2016

Peiris, HMP Gunarathne, AD Nuwan (2015) Sustainable Weed Management in the Commercial Tea Industry: The Case of Hapugastenne Estate, Maskeliya. Available at https://ssrn.com/abstract=2706978. Accessed 08 Apr 2017

Pope G, Annandale D, Morrison-Saunders A (2004) Conceptualising sustainability assessment. Environ Impact Assess Rev 24:595-616

Pretty J, Morison JIL, Hine R (2003) Reducing food poverty by increasing agricultural sustainability in developing countries Agric Ecosystems Environ 95(1):217-234

Provasnek AK, Sentic A, Schmid E (2017) Integrating Eco-Innovations and Stakeholder Engagement for Sustainable Development and a Social License to Operate. Corp Soc Responsib Environ Manag 24(3):173-185

Ravichandran R (2004) The impact of pruning and time from pruning on quality and aroma constituents of black tea. Food Chem 84(1):7-11

Ravichandran R, Parthiban R (1998a) The impact of mechanisation of tea harvesting on the quality of the South Indian CTC teas. Food Chem 63:61-64

Ravichandran R, Parthiban R (1998b) Changes in enzyme activities (polyphenol oxidase and phenylalanine ammonia lyase) with type of tea leaf and during black tea manufacture and the effect of enzymi supplementation of dhool on black tea quality. Food Chem 62(3):277-281

Rennings K (2000) Redefining innovation e eco-innovation research and the contribution from ecological economics. Ecol Econ 32:319-332

Rossi M (2014) Capital budgeting in Europe: confronting theory with practice. Int J Managerial Financ Account 6(4):341-356

Rothenberg S, Pil FK, Maxwell J (2001) Lean, green, and the quest for superior environmental performance. Prod Oper Manag 10:228-243

Schaltegger S, Etxeberria IÁ, Ortas E (2017) Innovating Corporate Accounting and Reporting for Sustainability - Attributes and Challenges. Sustain Dev 25(2):113-122

Selvendran RR (1970) Changes in the composition of the xylem exudate of tea plants (Camelliasinensis L.) during recovery from pruning. Ann Bot 34:825-833

Sroufe R, Montabon F, Narasimhan R, Wang X (2002) Environmental management practices: a framework. Greener Manag Int 40:23-44 
Sudhi KS (2013) Weedicides will affect local biodiversity: greens, The Hindu. Available at http://www.thehindu.com/news/ cities/Kochi/weedicides-will-affect-local-biodiversity-greens/article5282557.ece. Accessed 12 Dec 2016

Tea Research Association (TRA) (2015) Young Tea Management, Tocklai Tea Research Association of India. Available at http://www.tocklai.net/activities/tea-cultivation/young-tea-management/. Accessed 01 Mar 2016

UN Environment Programme (UNEP) (2008) Agriculture, Agro-biodiversity and Climate Change. UNEP, Bonn

Veleva V, Ellenbecker M (2001) Indicators of sustainable production: framework and methodology. J Clean Prod 9(6):519-549

Von Geibler J, Liedtke C, Wallbaum H, Schaller S (2006) Accounting for the social dimension of sustainability: experiences from the biotechnology industry. Bus Strategy Environ 15:334-346

Yamada A, Yamamoto T, Yoshimura Y, Gouda S, Kawashima S, Yamazaki N, Yamashita K, Kataoka M, Nagata T, Terada H, Pfeifferf DR, Shinohara Y (2009) Ca2+-induced permeability transition can be observed even in yeast mitochondria under optimized experimental conditions. Biochim Biophys Acta 1787(12):1486-1491

Submit your manuscript to a SpringerOpen ${ }^{\circ}$ journal and benefit from:

- Convenient online submission

- Rigorous peer review

Open access: articles freely available online

- High visibility within the field

Retaining the copyright to your article

Submit your next manuscript at $\gg$ springeropen.com 